\title{
Fifth Grade Students' Problem Solving Ability of Flood Disaster
}

\author{
Anisa Listiani ${ }^{1}$, M. Jaya Adi Putra ${ }^{1 *}$, Mahmud Alpusari ${ }^{1}$ \\ Department of Elementary Teacher Education, Faculty of Teacher Training and Education, \\ University of Riau, Pekanbaru, Indonesia \\ *jaya.adiputra@lecturer.unri.ac.id
}

Abstract

The research is aimed to identify and describe the ability of fifth grade students in solving problems of disaster mitigation. This study was implemented in a public elementary school in Kampar, Riau, Indonesia in 2019. The type of research was qualitative research. The subject of this study was 42 fifth grade students. Instruments were arranged to refer to problem-solving indicators. After the instruments were validated by experts and tested by students, it was then used to retrieve data. The data is categorized and grouped according to the device already created. Based on the results of the study it showed that the students ' ability has been in an excellent category in carrying out problems and examining problems, while their ability was a poor category in planning, implementing, and evaluating the solutions that have been made.

Keywords: disaster mitigation; flood; problem solving.

\section{INTRODUCTION}

Indonesia is a country that has high levels of natural disasters, such as floods, earthquakes, tsunamis, landslides, and so forth. Indonesia is a tropical country that has the characteristics of high rainfall during the rainy season. As a result in some places during the rainy season, there is a flood that raises many losses, both life, and property. Nearly every rainy season the flood disaster events often occur with varying locations and damage levels. Flooding is a natural occurrence that needs attention, as it can occur at any time and often results in loss of life, loss of property, and objects. Floods often occur in many countries especially in developing countries (Puturuhu, 2015).

Kampar Regency is one of the areas in Riau province which is partly prone to disaster, especially flood disaster. Flood disaster routine occurs in every annual, caused by high rainfall with a long duration so that the river in Kampar district is not able to hold a lot of water and cause the river water to overflow to the residents ' settlements.

One of the feelings of the direct impact of flooding in the Kampar area in SD Negeri 008 Kualu District of Kampar District mines, geographically located on the banks of the Kampar River, which is only approximately $1 \mathrm{~km}$ from the banks 
of the river. This school has always been the target of water overflow from the Kampar River. This condition resulted in the disruption of activities of learning activities in SD Negeri 008 Kualu. Water coming into the room resulted in the destruction of educational facilities and infrastructure in the school. Buildings, tables, chairs, cabinets, and books are wet and damaged so it cannot be used to learn. In this case students as the subject of education feel directly the impact of the flood event. School activities are canceled to automatically reduce the number of hours of study that can affect the decline in student learning performance.

Many incidents of natural disasters in the last ten years that hit the state of Indonesia, make disasters as a topic that is often discussed and should be resolved and resolved immediately, including the efforts to include disasters and disaster in the curriculum at the level of primary, secondary and tertiary education (Hermon, 2012).

This action is called a disaster mitigation action. The mitigation of the disaster was popularized in the year 2010, which is associated with the handling of disasters that occurred in various Indonesian archipelagos starting from flood disaster, Storm, fire, until the eruption of Mount Merapi that caused many casualties and materials (Hermon, 2015). The general purpose of such mitigation can be interpreted as an effort or action taken, which is found from the following definition, disaster mitigation is "a series of efforts to reduce disaster risk, through physical development and awareness and enhancement of disasterfacing threats" (UU No. 24 the year 2007).

Based on the background description that has been elaborated, the researcher conducted the research under the title "Problem Solving ability flood disaster mitigation class $\mathrm{V}$ elementary school students 008 Kualu District Mines Kampar District".

\section{METHODS}

The study was conducted in SD Negeri 008 Kualu from October $21^{\text {st }}$ to December $3^{\text {rd }}, 2019$. The subject of this study was all students of class $V$. The type of research is conducted by qualitative research.

The research instruments are used tests given to students containing questions made based on problemsolving indicators. The data is obtained qualitative data. The data sources were obtained from the students ' answers that filled the tests containing the questions. The data obtained is analyzed using a Category Assessment section of problem-solving capabilities, subsequently analyzed using inductive data analysis techniques.

\section{RESULTS}

Based on students' answer to the problem-solving tasks, we categorized students' answers by very well, good and less well. The results are presented in table 1. 
Table 1. Recapitulation of research results aspects of problem solving

\begin{tabular}{|c|c|c|c|}
\hline \multirow{2}{*}{ Aspects } & \multicolumn{3}{|c|}{ Category } \\
\hline & Excellent & Good & Poor \\
\hline $\begin{array}{l}\text { To provide a } \\
\text { problem }\end{array}$ & $67.4 \%$ & $25.4 \%$ & $7.1 \%$ \\
\hline $\begin{array}{l}\text { Check for } \\
\text { problems }\end{array}$ & $38.1 \%$ & $38.9 \%$ & $23 \%$ \\
\hline $\begin{array}{l}\text { Planning } \\
\text { Solutions }\end{array}$ & $4.8 \%$ & $21.4 \%$ & $73.8 \%$ \\
\hline $\begin{array}{l}\text { Implementing a } \\
\text { prepared Plan }\end{array}$ & $17.9 \%$ & $14.3 \%$ & $67.8 \%$ \\
\hline Evaluate & $30.2 \%$ & $19.8 \%$ & $50 \%$ \\
\hline
\end{tabular}

According to the table 1 , it shows that the aspect of the problem is to assess and examine the problem students have entered in a good category, while in the planning aspects of the solution, implementing the plan that has been made and evaluating the students still in the category is not good.

\section{DISCUSSION}

\section{a. To provide a problem}

Based on data table 1 , in the aspect of the issue of the problem of many students who have entered the category is very good and good, it can be seen from the answers of students who can mention more than three facts that occur in the school and its environment after a flood disaster. Students mention problems that occur in schools when affected by flooding such as: damage to tables and chairs, the recitation of school buildings, the fresher of school walls, a lot of books that are wet, damaged and lost, classes become smelly and dirty, the amount of garbage is scattered, and the environment becomes dirty. In line with the submitted Rachmawati (2017) that flooding can cause many problems such as damaging various facilities and infrastructures that inflict material losses and harm the souls of humans and animals. Students are able to mention and give reasons to the disaster category. Students mentioned that the flood disaster belongs to the category of natural disasters and mentions the reason because the flood disaster causes environmental damage. Students are also able to mention the time and place of the flood disaster, because students experience directly in their daily life.

As for the category of poor in the aspect of the issue of the students write down the answers to facts that occur after the flood disaster is less than three facts, or some students are not able to fulfill the answers to the questions given. Students do not mention the category of flood disaster including natural disasters and not able to give reasons why flood disaster belongs to the category of natural disasters or not.

\section{b. Checking the problems}

According to table 1 , the aspect of examining the problem of students answers has been in good category and very good because students are able to mention four or more causes of flood disaster. Students mentioned that the cause of flood disaster due to high rainfall, settlements are in lowland, absence of forest or deforestation, disposal of garbage into rivers and river narrowing. Students are able to mention the consequences of a flood disaster that occurs for themselves and for the 
environment in which he lived. Students mention the impact caused by the flood disaster is the emergence of various seeds of illness, damaged and loss of property, and the environment becomes dirty due to garbage and mud carried water. Students are also able to mention actions that had been done before the flood disaster occurred, when the flood disaster occurred and after the flood disaster occurred.

On the aspect of examining the problem only a few students answer that shows still be in the less good category. Students who are in the category of poor writing down the cause of the flood disaster are less than four causes and students are unable to mention the consequences of a flood disaster for themselves as well as for their environment, and students are only able to mention the actions he once performed in only one category of the three categories requested. Students are not able to fulfill answers to the questions given.

\section{Planning solutions}

Seen in table 1, that is, the aspect of planning solutions very little answer students are in the category of good and very good, this is because only a few students can mention problems that occurred before the flood, during the flood, after the flood and able to mention how to handle it from each category and mention more than three actions that will be done to reduce the risk of flood disaster. Students mention the actions taken to reduce the risk of flooding, among others, by making a wells, planting more large trees, maintaining the cleanliness of the drains, raising the house building or moving the house to a flood-free area. This is in accordance with the opinion of Susila (2019) The action that can be done to reduce the risk of flooding is to make a wells, plant more large trees, maintain the cleanliness of the drains, and move the residence to a higher area.

While more than half of students ' answers to the aspect of planning solutions are still in the less good category, it is because students are only able to mention less than three actions that will be taken to reduce the risk of flooding and are only able to mention the problems that occur along with how to deal with only one of the three categories requested. In addition there are some students who write answers but are unable to fulfill answers to the questions given.

\section{d. Implementing a plan that has been made}

In the 4th aspect of carrying out a plan that has been made very few students answer that shows already in good category and very good. Only a few students are able to mention the steps that will be taken to address the issue of flooding before, during, and after and mentioning two or more parties, the agency or the institution to be contacted to help implement the resolving steps of the flood disaster problem. Students are not a national agency for Disaster Management (BNPB), teachers, village 
heads, and people who will be contacted to help implement a flood-solving problem. This is in accordance with the aforementioned Rachmawatie (2017), to minimize losses caused by government disasters forming a body in charge of helping coordinate the disaster i.e. BNPB (National Disaster Management Agency), and for in the area of parties that can help carry out the steps of flood problem solving are community leaders, Lurah, village heads, as well as RT and RW.

In this 4th aspect more than half of the students ' answers are in less good category. This is because students have not been able to give solution what to do to overcome the flood problem, so that students cannot afford to implement the solution and students are only able to mention one of the three categories requested is at the time of the flood disaster, before the flood disaster, and after the flood disaster occurred.

\section{e. Evaluate}

On the aspect of evaluating the solution almost from half the students' answer that shows already are in good and very good category. Students write the answer that a given solution can and can be used to address flood problems. Students write down a reason why the solution it gives can be used to address flood problems. Students are also able to mention more than two ways to convey and communicate the solution he has made to be delivered to the multitude. Students mention how to convey them by creating flood-themed posters, making videos about flooding, and making posts about flooding distributed through social media. This is in line with the delivered Puturuhu (2015), the implementation of the flood information system with direct dissemination to the community and the publication of press releases or explanations to the press and dissemination of information about the flood through print and electronic mass media, i.e. TV station, radio stations, online media, blogs, official web, social media and so on.

In the latter aspect of evaluating some students still entering the category of less good, this is caused by the inability of the students to estimate the solution that will be obtained from disaster mitigation actions that have been made and not knowing the right media to communicate the disaster mitigation solutions and students write answers but not able to fulfill the answers to the questions given Students mention less than two ways to convey and communicate the solution he has made to be delivered to the multitude.

\section{CONCLUSION}

The results of the study shows that students have a very good ability to verify problems and examine problems, but students are still lacking in planning, implementing and evaluating flood disaster mitigation solutions so that the problem solving skills of flood disaster mitigation students are still in less good category.

Based on the results, the researcher recommended to all of components school, teachers and headmaster, to 
include disaster mitigation studies into the school curriculu. It is advisable for teachers to conduct simulated activities for students to face a flood disaster.

\section{REFERENCES}

BNPB. (2017). Buku Saku Tanggap Tangkas Tangguh Menghadapi Bencana. Jakarta : Badan Nasional Penanggulangan Bencana.

Futuruhu, F. (2015). Mitigasi Bencana dan Penginderaan Jauh. Yogyakarta : Graha Ilmu
Hermon, D. (2012). Mitigasi Bencana Hidrometeorologi. Padang : UNP Press

Hermon, D. (2015). Geografi Bencana Alam. Jakarta: PT Raja Garafindo Persada

Rachmawatie, S. J. (2017). Ensiklopedia Mitigsi Bencana Banjir. Surakarta: Borobudur Inspira Nusantara

Susila, P. H. (2019). Bencana Alam Hidrologi. Jakarta : PT Pustaka Tiga Kelana

Undang- Undang Nomor 24 Tahun 2007 tentang Penanggulangan Bencana. 